\title{
Ghrelin in neonatal rats: distribution in stomach and its possible role
}

\author{
T Hayashida, K Nakahara, M S Mondal ${ }^{1}$, Y Date $^{1}$, M Nakazato ${ }^{1}$, \\ M Kojima ${ }^{2}$, K Kangawa ${ }^{2}$ and N Murakami \\ Department of Veterinary Physiology, Faculty of Agriculture, University of Miyazaki, Miyazaki 889-2155, Japan \\ ${ }^{1}$ Third Department of Internal Medicine, Miyazaki Medical College, Kiyotake, Miyazaki 889-1692, Japan \\ ${ }^{2}$ National Cardiovascular Center Research Institute, Osaka 565-8565, Japan \\ (Requests for offprints should be addressed to N Murakami; Email: a0d201u@cc.miyazaki-u.ac.jp)
}

\begin{abstract}
Ghrelin, a 28 amino acid peptide, has recently been isolated from the rat stomach as an endogenous ligand for the GH secretagogue receptor. The fact that administration of ghrelin, centrally or peripherally, stimulates both food intake and GH secretion suggests that stomach ghrelin has an important role in the growth of rats. We used immunohistochemistry and radioimmunoassay to determine the age at which ghrelin-immunostained cells begin to appear in the rat stomach. Ghrelinimmunoreactive cells were found to be expressed in the fetal stomach from pregnancy day 18. The number of ghrelin-immunoreactive cells in the fetal stomach increased as the stomach grew. The amount of ghrelin in the glandular part of the rat stomach also increased, in an
\end{abstract}

age-dependent manner, from the neonatal stage to adult. Eight hours of milk restriction significantly decreased the ghrelin concentration in the stomachs of 1-week-old rats, and increased the ghrelin concentration in their plasma. Administration of ghrelin to 1- and 3-week-old rats increased plasma GH concentrations. The daily subcutaneous administration of ghrelin to pregnant rats from day 15 to day 21 of pregnancy caused an increase in body weight of newborn rats. In addition, daily subcutaneous administration of ghrelin to neonatal rats from birth advanced the day of vaginal opening from day $30 \cdot 7 \pm 0 \cdot 94$ to day $27 \cdot 9 \pm 0 \cdot 05$. These results suggest that ghrelin may be involved in neonatal development.

Journal of Endocrinology (2002) 173, 239-245

\section{Introduction}

Growth hormone (GH) secretagogues (GHSs), which are synthetic peptides or non-peptides, stimulate release of GH from the anterior pituitary by acting on the hypothalamus (Smith et al. 1999). Although an endogenous GHS receptor (GHS-R) has been isolated and cloned, the endogenous GHS ligand was difficult to identify (Howard et al. 1996, McKee et al. 1997a,b). Recently, the peptide ghrelin was purified from rat stomach, and was identified as an endogenous ligand for GHS-R (Kojima et al. 1999). Ghrelin consists of 28 amino acids, including an $\mathrm{O}-n-$ octanoylated $\mathrm{Ser}^{3}$ residue, which is essential for $\mathrm{GH}$ release. An analogue of ghrelin, des-Gln14-ghrelin, has also been purified from rat stomach, and is a second endogenous ligand for GHS-R (Hosoda et al. 2000).

Immunohistochemical studies, including in situ hybridization, have revealed that, in the gastrointestinal tract, ghrelin is produced mainly from the neck to the base of the oxyntic glands, especially in the X/A-like cells, the physiological role of which is unknown (Date et al. 2000a). In addition to playing a part in GH release (Kojima et al.
1999, Date et al. 2000b), ghrelin is involved in various physiological functions (Tschop et al. 2000, Asakawa et al. 2001, Date et al. 2001, Nakazato et al. 2001). We have already demonstrated that intracerebroventricular (i.c.v.) or intravenous (i.v.) administration of ghrelin gives rise to an intense orexigenic action (Nakazato et al. 2001). Daily treatment with ghrelin increases food intake and body weight gain in rats (Tschop et al. 2000, Nakazato et al. 2001). It has also been suggested that, in the rat, ghrelin participates in gastric acid secretion through the vagus system (Date et al. 2001). These results suggest that ghrelin may have an important role in energy balance. If this is so, there is a possibility that ghrelin may be involved in neonatal development or milk intake. We therefore examined the localization of ghrelin cells and the content of ghrelin in the glandular part of the rat fetal stomach, and the effect of milk restriction on ghrelin concentrations in the peripheral blood and stomach of neonatal rats. In addition, we examined whether a single injection of ghrelin into neonates increases GH secretion, and whether daily treatment with ghrelin advances the rate of sexual maturation, for example vaginal opening. 


\section{Material and Methods}

Adult male and female Wistar rats weighing about $400 \mathrm{~g}$ or $250 \mathrm{~g}$ respectively (Charles River Japan Inc., Shiga, Japan) were kept under a lighting regimen of $12 \mathrm{~h}$ light:12 h darkness (lights on at $0700 \mathrm{~h}$ ) and a temperature of $23 \pm 1{ }^{\circ} \mathrm{C}$. Animals were supplied with standard laboratory chow and water, available ad libitum. The day when sperm was found in vaginal smears was defined as day 0 of pregnancy.

To pinpoint the location of ghrelin in the stomach, pregnant rats were decapitated at day $18(n=3)$ or $20(n=4)$ of pregnancy, and the fetuses and stomachs were removed. All procedures were carried out in accordance with the Japanese Physiological Society's guidelines for animal care. The tissues were immediately rinsed with saline and fixed in $4 \%$ paraformaldehyde and $0 \cdot 2 \%$ picric acid in $0 \cdot 1 \mathrm{M}$ phosphate buffer for 2 days, then incubated in $0.1 \mathrm{M}$ phosphate buffer containing $20 \%$ sucrose for $24 \mathrm{~h}$ at $4{ }^{\circ} \mathrm{C}$. The fetal glandular stomach was cut into sections $12 \mu \mathrm{m}$ thick by cryostat at $-20^{\circ} \mathrm{C}$. The sections were then thaw-mounted on gelatin-coated glass slides and air-dried for $10 \mathrm{~min}$. After pretreatment with $0 \cdot 3 \%$ hydrogen peroxidase for $1 \mathrm{~h}$ to inactivate endogenous peroxidases, followed by incubation with normal goat serum for $1 \mathrm{~h}$ to block non-specific binding, all sections were incubated overnight at $4{ }^{\circ} \mathrm{C}$ with anti-ghrelin antiserum. The polyclonal antibody used in this study was produced in rabbits, against the $\mathrm{N}$-terminal fragment of rat ghrelin. Details of preparation and characterization of the antibody have been described by Date et al. (2000a). The rat anti-ghrelin antibody (antiserum no. G606) specifically recognizes ghrelin with $n$-octanoylated $\mathrm{Ser}^{3}$, and does not recognize des-acyl ghrelin. The final dilution of anti-ghrelin antiserum used in the immunohistochemistry was 1/10 000 . After being washed with phosphate-buffered saline (PBS), the sections were stained by the avidin-biotin-peroxidase complex method (Vectastain Elite ABC kit, Vector Lab. Inc., Burlingame, CA, USA), with a diaminobenzidine (DAB) substrate kit (Vector Lab.) at room temperature. Immunostaining for ghrelin cells in the stomachs of each of four rats 1 day and 1, 3, 4 and 5 weeks old was also carried out using the methods described above. Control studies were performed with normal rabbit serum or anti-ghrelin that had been absorbed with $10 \mu \mathrm{g}$ rat ghrelin.

To determine the content of ghrelin in the glandular part of the neonatal stomach, radioimmunoassay (RIA) of ghrelin was undertaken using a method described previously (Date et al. 2000a). A group of four rats was killed by decapitation every week from 1 week to 9 weeks of age. Each experiment was repeated twice. Synthetic rat $\left[\mathrm{Tyr}^{29}\right]$ ghrelin(1-28) was radioiodinated by the lactoperoxidase method. The iodine-125-labeled peptide was purified on a TSK ODS SIL 120A column (Tosoh Co. Ltd, Tokyo, Japan) by reverse-phase high-performance liquid chromatography. The RIA incubation buffer was $50 \mathrm{mM}$ sodium phosphate (pH 7.4) containing $0.5 \%$ bovine serum albumin (BSA) treated with $\mathrm{N}$-ethylmaleimide, $80 \mathrm{mM} \mathrm{NaCl}, 25 \mathrm{mM}$ EDTA, 0.05\% $\mathrm{NaN}_{3}$, and $0.5 \%$ Triton X-100. A diluted sample or the standard solution $(100 \mu \mathrm{l})$ was incubated for $24 \mathrm{~h}$ with $100 \mu \mathrm{l}$ of anti-ghrelin antiserum (final dilution 1/620 000). The tracer solution (16 000 c.p.m. in $100 \mu \mathrm{l})$ was added, and each mixture was incubated for $24 \mathrm{~h}$. Bound and free ligands were separated by a second antibody $(200 \mu \mathrm{l})$. All procedures were carried out at $4{ }^{\circ} \mathrm{C}$. All plasma samples were assayed in duplicate. The half-maximum inhibition of rat ghrelin(1-28) on the standard RIA curve with anti-ghrelin(1-11) antiserum (no. G606) was $3.8 \mathrm{fmol} /$ tube. The dilution curves for the extracts of rat stomach paralleled both standard curves. The respective intra- and interassay coefficients of variation of RIA for the ghrelin $\mathrm{N}$-terminal fragment (no. G606) were $3 \cdot 5 \%$ and $3 \cdot 2 \%$ at $50 \%$ binding. The recovery rates of rat ghrelin(1-28) $(1 \mathrm{ng})$ and ${ }^{125}$ I-rat ghrelin(1-28) (5000 c.p.m.) added to the tissue homogenates in the extraction performed with Sep-Pac C-18 cartridges were $92 \cdot 2 \pm 0 \cdot 4 \%$ (mean \pm S.E.M.) and $88.9 \pm 0.6 \%$ (mean \pm S.E.M.) respectively.

For the assessment of ghrelin concentration in peripheral blood and stomach after $8 \mathrm{~h}$ of milk restriction, four male pups were selected from each litter on postpartum day 7 and separated from their mothers for $8 \mathrm{~h}$ (from $0900 \mathrm{~h}$ ). The remaining three nursing male pups in each group were used as controls. Each experiment was repeated twice. Immediately after peripheral blood was collected by heart puncture, the stomachs were removed. Blood was drawn into chilled polypropylene tubes containing EDTA. $2 \mathrm{Na}(1 \mathrm{mg} / \mathrm{ml}$ blood), aprotinin (500 $\mathrm{U} / \mathrm{ml}$ blood $)$ and Pefabloc SC $(2 \cdot 4 \mathrm{mg} / \mathrm{ml}$ blood; Roche, Nutley, NJ, USA), and then centrifuged. After the plasma had been diluted twofold with $0.9 \%$ saline, it was applied to a Sep-Pak C-18 cartridge and washed with saline and $10 \% \mathrm{CH}_{3} \mathrm{CN}$ solution containing $0 \cdot 1 \%$ trifluoroacetic acid (TFA). The absorbed peptides were eluted with $60 \%$ $\mathrm{CH}_{3} \mathrm{CN}$ solution containing $0 \cdot 1 \%$ TFA, lyophilized, then subjected to RIA. The stomach tissues were immediately heated at $95-100{ }^{\circ} \mathrm{C}$ for $5 \mathrm{~min}$ in a 10 -fold volume of water, to inactivate the intrinsic proteases, then cooled to $4{ }^{\circ} \mathrm{C}$. $\mathrm{CH}_{3} \mathrm{COOH}$ and $\mathrm{HCl}$ were then added to respective final concentrations of $1 \mathrm{M}$ and $20 \mathrm{mM}$, after which the tissues were homogenized in a Polytron for $10 \mathrm{~min}$. The homogenate was centrifuged at $11500 \boldsymbol{g}$ for $30 \mathrm{~min}$. The supernatants were applied to a Sep-Pac C-18 cartridge, and the peptides eluted with $60 \%$ acetonitrile solution containing $0 \cdot 1 \%$ TFA and lyophilized, then subjected to RIA.

To examine the effect of a single injection of ghrelin on GH secretion in neonates, six male pups at 1 and 3 weeks old were selected from each litter and were injected with $1 \mathrm{nmol}$ ghrelin subcutaneously (s.c.) at 0800 h. Remaining male pups in the same litters were injected with saline. The same experiment was repeated three times. Twenty 
minutes after injection, blood samples were collected after decapitation of the animal. GH was measured by radioimmunoassay as described previously (Date et al. 2000b).

To examine the effect of daily injections of ghrelin into pregnant rats on the body weight of newborn rats, eight pregnant rats were each injected s.c. with saline or $3 \mathrm{nmol}$ ghrelin three times per day at 0800, 1300 and $1700 \mathrm{~h}$. On the day of delivery, body weights of newborn rats were measured. To examine the effect of daily injections of ghrelin on the time of vaginal opening, six female pups were selected from each litter and were injected with ghrelin at $0800 \mathrm{~h}$ every day. Remaining female pups from the same litters were injected with saline. Two groups were used in this experiment. In one group, $0 \cdot 5,1 \cdot 0$ and $1.5 \mathrm{nmol}$ ghrelin was injected s.c. from the day of birth to day 15 , from days 16 to day 30 , and from day 31 to the day of vaginal opening respectively. In the other group, 1.0 and $1.5 \mathrm{nmol}$ ghrelin was injected s.c. from the day of birth to day 15 and from day 16 to the day of vaginal opening respectively. The same experiment was repeated twice. The day of vaginal opening was determined by visual inspection.

The statistical analysis was carried out by analysis of variance with the post hoc Fisher test.

\section{Results}

Stomach concentrations of ghrelin measured by RIA using antibody specific for the N-terminal fragment of ghrelin increased linearly from 1 week until 5 weeks of age, when they reached a plateau (Fig. 1). Immunohistochemistry revealed that cells immunostained for ghrelin were already present, albeit in very low numbers, in the gastric mucosa of the fetus on pregnancy days 18,20 and 22. The numbers of these cells increased gradually from postnatal day 1. Ghrelin-immunoreactive cells were abundant in the bases of the oxyntic glands in 1-week-old rats, and then became widely distributed from the necks to the bases of the gastric glands at 3-5 weeks of age (Fig. 2). No immunoreactive cells were detected in the gastric mucosa of the rat stomach when normal rabbit serum (not shown) or the antisera were absorbed with excessive ghrelin (Fig. $\left.2 F^{\prime}\right)$. Eight-hour milk restriction significantly reduced ghrelin concentrations in the stomach $(P<0.05)$ but, in contrast, increased those in plasma $(P<0 \cdot 05)$ (Fig. 3). A single injection of $1 \mathrm{nmol}$ ghrelin into 1 - or 3-week-old neonates caused a significant increase in $\mathrm{GH}$ secretion (Fig. 4A, B). The daily administration of a high dose of ghrelin $(1.0 \mathrm{nmol}$ ghrelin injected s.c. from the day of birth to day 15 , followed by treatment with $1.5 \mathrm{nmol}$ ghrelin until the day of vaginal opening) advanced the day of vaginal opening in immature female rats from day $30.7 \pm 0.94$ to day $27.9 \pm 0.05 \quad(P<0 \cdot 05) \quad$ (Fig. 5A),

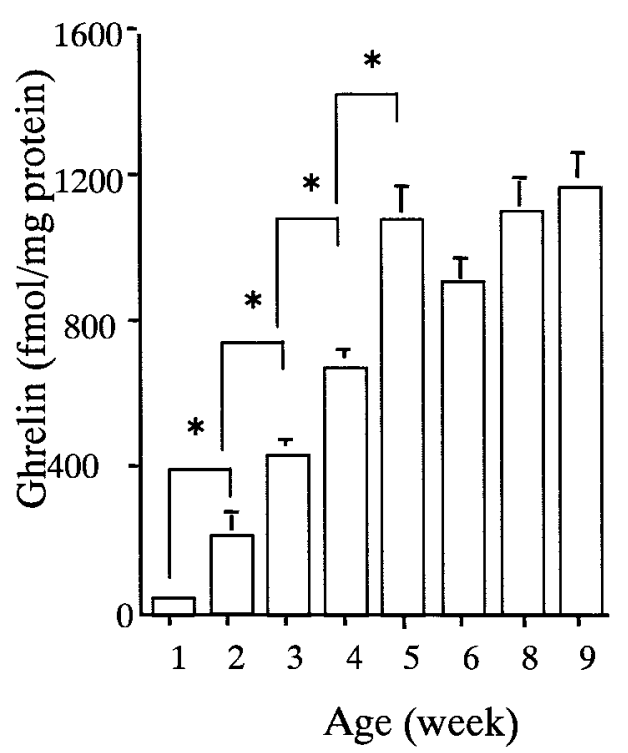

Figure 1 Changes in stomach ghrelin content during neonatal development. Ghrelin concentrations increased linearly until 5 weeks of age. Bars and T-markers represent mean values \pm S.E.M. $(n=8) .{ }^{*}$ Significant differences $(P<0 \cdot 05)$.

without a significant increase in body weight in comparison with that in saline-treated rats $(P<0 \cdot 1$ for ghrelin compared with control; data not shown). The daily administration of ghrelin into pregnant rats during late pregnancy caused a significant increase in body weight in newborn rats (Fig. 5B).

\section{Discussion}

Ghrelin-producing cells have been detected in the rat hypothalamic arcuate nucleus and the oxyntic glands of rat and human stomach (Kojima et al. 1999). From their morphology and distribution, the immunostained cells in the stomach were considered to be X/A-like cells, the hormonal product of which was previously unclear (Date et al. 2000a). In our study, the cells that were immunoreactive for ghrelin in the fetal and neonatal stomach were similarly round and compact, with electron-dense granules in the cytoplasm, suggesting that secretion of ghrelin from the fetal stomach might already have started during late pregnancy. Recently, Lee et al. (2002) reported that ghrelin was not detectable in the fetal rat stomach in northern blotting analysis; however, ghrelin mRNA expression and peptide concentrations increased dramatically during the second and third postnatal weeks. The discrepancy in detection of ghrelin in fetal stomach between our data and the findings of Lee et al. (2002) may be due to differences of analytical method. 

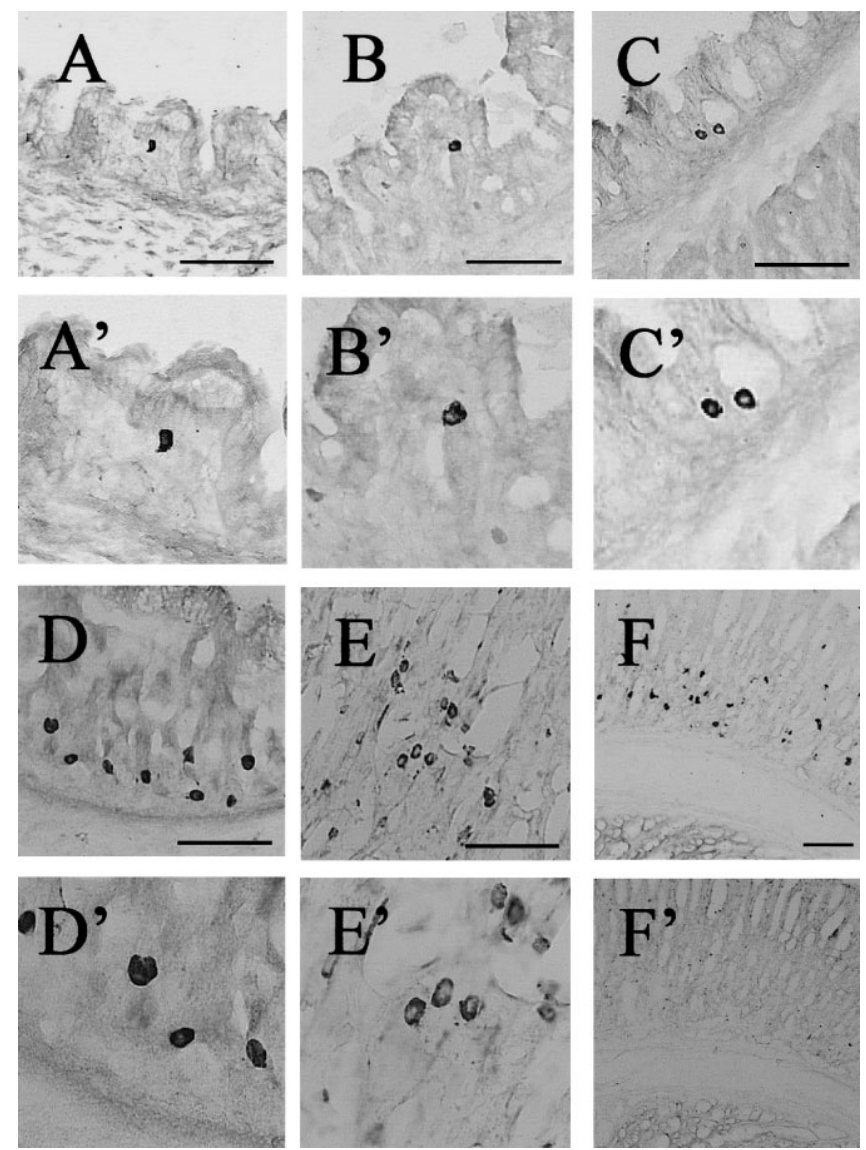

Figure 2 Localization of ghrelin-immunoreactive cells in the neonatal and fetal stomach. Antiserum against rat ghrelin (1-11) was used for detection. Few ghrelin cells were expressed in the gastric mucosa on pregnancy days 18 (A), 20 (B), or 22 (C). The ghrelin-positive cells (black cells) were distributed mainly in the bases of the oxyntic glands in 1 -week-old pups (D), but by 5 weeks of age (E) they were more widespread, appearing from the necks to the bases of the oxyntic glands. (Photographs for rats at 3 and 4 weeks of age have been omitted, as they were almost identical to those for rats of 5 weeks of age). Scale bars: A-F, $0 \cdot 1 \mathrm{~mm} ; \mathrm{A}^{\prime}-\mathrm{E}^{\prime}$ are $2 \times$ magnifications of $\mathrm{A}-\mathrm{E}$ respectively. No immunoreactive cells were detected in the gastric mucosa of the rat stomach when the antisera were absorbed with excessive ghrelin ( $\mathrm{F}^{\prime}$ compared with $\mathrm{F}$ ).

These observations prompted us to ask why ghrelin is synthesized in the fetal and neonatal stomach. Ghrelin has so far been shown to have several physiological roles. Firstly, it is likely that the most typical role of ghrelin is stimulation of GH secretion (Kojima et al. 1999, Date et al. 2000b, Arvat et al. 2000). Administration of ghrelin either centrally or peripherally increases $\mathrm{GH}$ secretion in a dose-dependent manner in rats and humans. Secondly, ghrelin increases food intake. I.c.v. injection of antiserum to ghrelin before exposure to a $12-\mathrm{h}$ period of darkness decreases food intake for the full $12 \mathrm{~h}$ of darkness, suggesting that endogenous ghrelin is involved in the regulation of daily food intake (Nakazato et al. 2001). It has also been reported that the stimulatory effect of ghrelin on food intake is due to the stimulation of neuropeptide $\mathrm{Y}$ and agouti-related peptide (Nakazato et al. 2001). Thirdly, ghrelin stimulates gastric acid secretion. I.c.v. injection of ghrelin increases gastric acid output in a dose-dependent manner in urethane-anesthetized rats, and this stimulation is blocked by vagotomy or administration of atropine (Date et al. 2001). As the fetus has no need to take food orally, it is possible that ghrelin acts directly on the fetal pituitary gland and stimulates GH secretion. In the present study, it was confirmed that ghrelin also stimulates GH secretion 


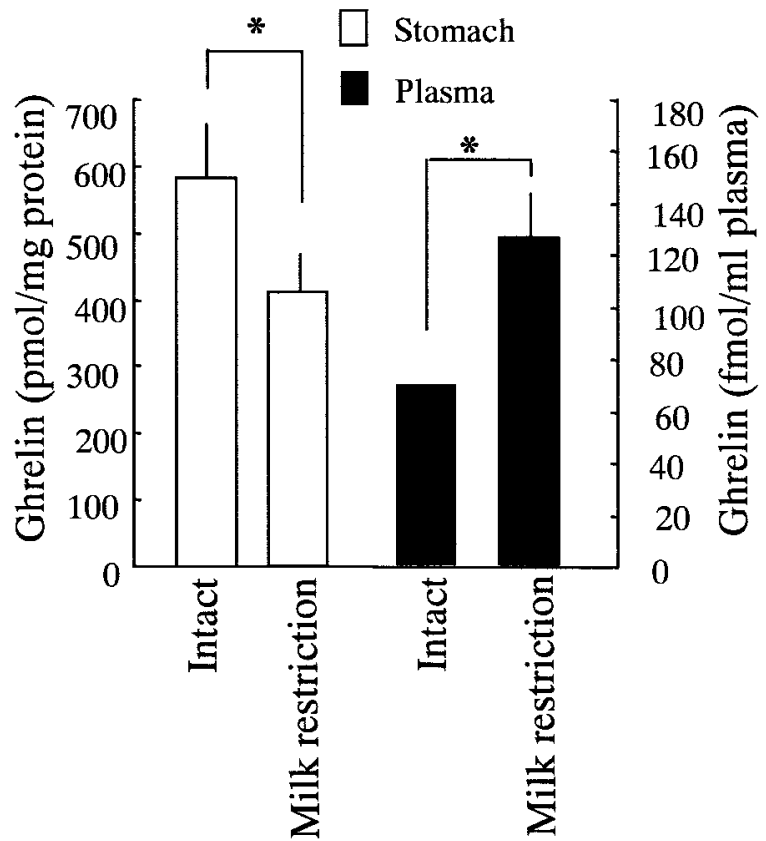

Figure 3 Effect of 8-h milk restriction on stomach and plasma ghrelin concentrations in 1-week-old pups. White and black bars and T-markers represent mean \pm S.E.M. stomach and plasma concentrations of ghrelin respectively $(n=6-8)$. *Significant differences $(P<0 \cdot 05)$.

in 1- and 3-week-old neonates. Recently, it has been reported that the effect of peripheral administration of ghrelin on GH secretion is blocked by vagotomy, and that the neuronal activity of the vagus efferent is affected by i.v. injection of very small amounts (fmol) of ghrelin (Asakawa et al. 2001). It has been hypothesized that peripheral ghrelin may act on peripheral sensors, so that the afferent signal then stimulates GH secretion. The existence of peripheral sensors for ghrelin may be indicated by the fact that GHS-R mRNA is distributed in various peripheral organs, such as the stomach and intestine (Guan et al. 1997, McKee et al. 1997b, Date et al. 2000a). If this hypothesis is correct, then the presence of a small amount of ghrelin in the fetal and neonatal stomach may stimulate GH secretion. In our study, stomach ghrelin content increased with growth postpartum. This observation is consistent with the distribution of cells that are immunoreactive for ghrelin, because the distribution of these cells spreads from the neck to the base of the gastric gland as the neonate ages. Increased concentrations of ghrelin in the stomach during infancy may be related to increased gastric acid output, GH secretion and milk intake. An 8-h restriction of milk caused an increase and decrease in ghrelin concentrations in the blood and stomach respectively. Probably, this reciprocal pattern of ghrelin
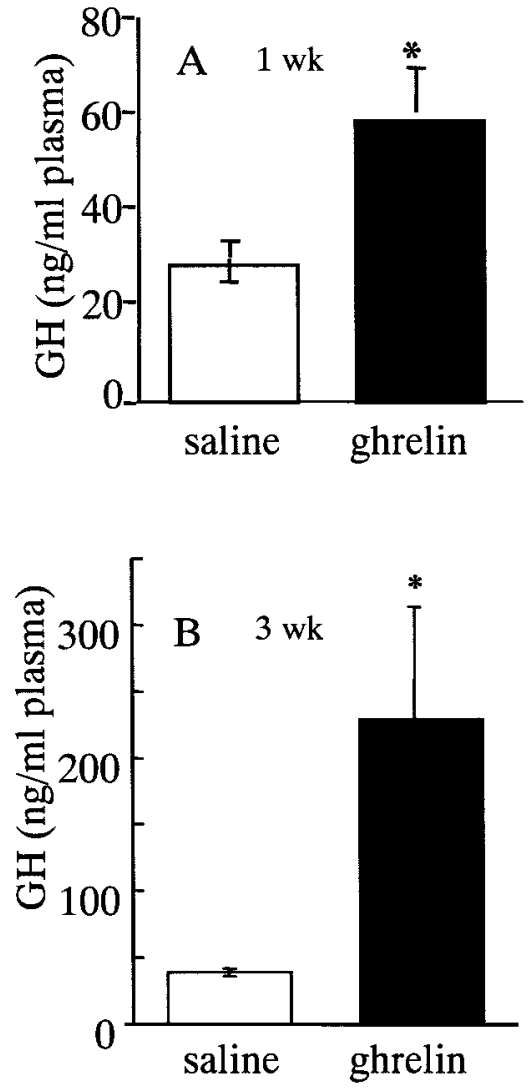

Figure 4 Effect of a single s.c. injection of ghrelin on $\mathrm{GH}$ secretion in (A) 1-week-old and (B) 3-week-old pups. Bars and T-markers represent mean values \pm S.E.M. $(n=18)$. Note that the scale on the $\mathrm{Y}$ axis differs between $(\mathrm{A})$ and $(\mathrm{B})$. * Significant differences $(P<0 \cdot 05)$.

concentrations between blood and stomach indicates that ghrelin is secreted from stomach to blood in neonatal rats. This finding also suggests that ghrelin in the blood may be involved in stimulating the appetite in order to increase milk intake.

The fact that daily injection of ghrelin advanced the day of vaginal opening by about 2 days without an associated significant increase in body weight suggests that ghrelin may also be involved in sexual maturation. We previously reported that continuous treatment with ghrelin increased body weight, in addition to food intake, in adult rats (Nakazato et al. 2001), and we do not know why daily injection of ghrelin did not increase the body weight in neonatal rats. However, neonatal rats would never be able to take an excess of milk, even if their appetite was stimulated by ghrelin. Further studies are required to elucidate the mechanism of ghrelin in sexual maturation and the relationship between ghrelin and the reproductive axis. The daily administration of ghrelin into pregnant rats 

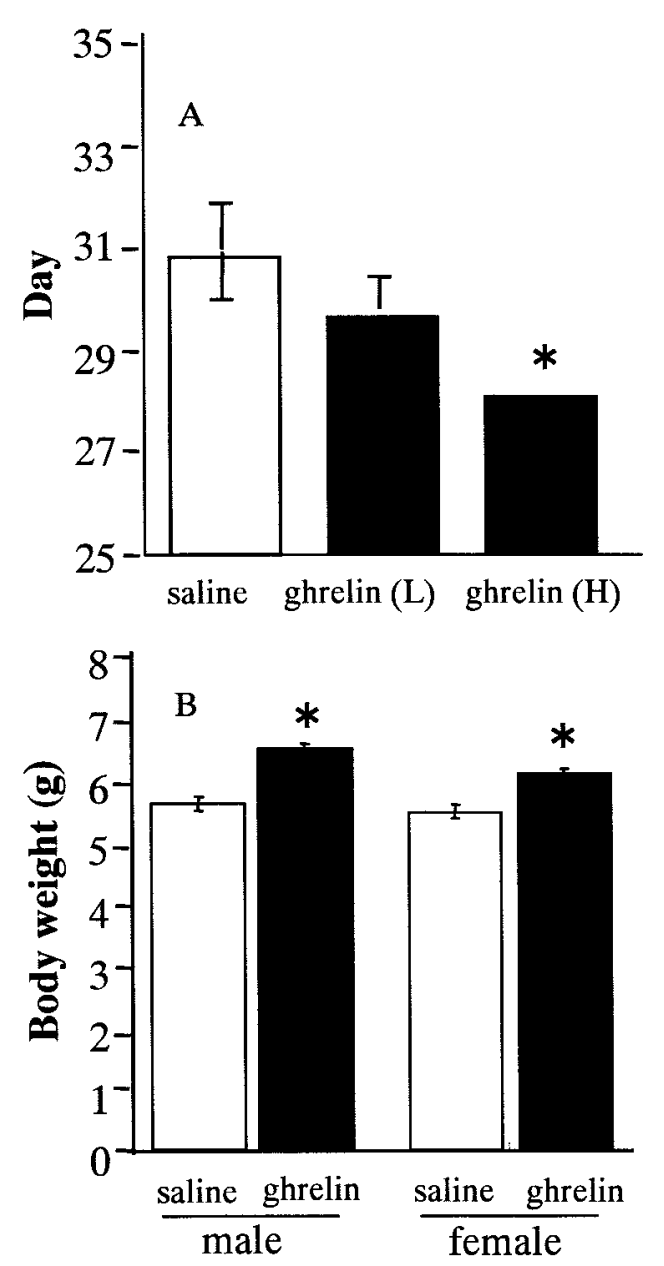

Figure 5 Effect of daily injection of ghrelin on the day of vaginal opening in immature rats (A), and effect of daily injection of ghrelin into pregnant rats on the body weight of newborn rats (B). (A) Ghrelin (L): $0.5,1.0$ and $1.5 \mathrm{nmol}$ ghrelin were injected s.c. from the day of birth to day 15 , from day 16 to day 30 , and from day 31 to the day of vaginal opening respectively. Ghrelin $(\mathrm{H}): 1 \cdot 0$ and $1.5 \mathrm{nmol}$ ghrelin were injected s.c. from the day of birth to day 15 and from day 16 to the day of vaginal opening respectively. The $\mathrm{Y}$ axis represents the day of vaginal opening. (B) Ghrelin $3 \mathrm{nmol}$ was injected s.c. three times per day from day 15 to day 22 of pregnancy. Bars and T-markers represent mean values \pm S.E.M. $(n=12)$. ${ }^{*}$ Significant differences $(P<0 \cdot 05)$.

caused an increase in body weight of newborn rats, suggesting that, if blood concentrations of ghrelin in pregnant rats increase during late pregnancy, this may influence fetal body weight. In this study, it was unclear whether ghrelin injected into the mother directly affected the fetus through the placenta, or if ghrelin-induced GH in the mother indirectly affected fetal body weights. Nevertheless, the present study demonstrates that ghrelin may have an important role in neonatal development, including sexual maturation, in rats.

\section{Acknowledgments}

This research was supported by the Nestle Science Promotion Committee, Skylark Food Science Research Institute and a grant-in-aid for Scientific Research (B) from the Japan Society for the Promotion of Science.

\section{References}

Arvat E, Di Vito L, Broglio F, Papotti M, Muccioli G, Dieguez C, Casanueva FF, Deghenghi R, Camanni F \& Ghigo E 2000 Preliminary evidence that ghrelin, the natural GH secretagogue (GHS)-receptor ligand, strongly stimulates $\mathrm{GH}$ secretion in humans. Journal of Endocrinological Investigation 23 493-495.

Asakawa A, Inui A, Kaga T, Yuzuriha H, Nagata T, Ueno N, Makino S, Fujimiya M, Niijima A, Fujino MA \& Kasuga M 2001 Ghrelin is an appetite-stimulatory signal from stomach with structural resemblance to motilin. Gastroenterology 120 337-345.

Date Y, Kojima M, Hosoda H, Sawaguchi A, Mondal MS, Suganuma T, Matsukura S, Kangawa K \& Nakazato M 2000a Ghrelin, a novel growth hormone-releasing acylated peptide, is synthesized in a distinct endocrine cell type in the gastrointestinal tracts of rats and humans. Endocrinology 141 4255-4261.

Date Y, Murakami N, Kojima M, Kuroiwa T, Matsukura S, Kangawa K \& Nakazato M $2000 b$ Central effects of a novel acylated peptide, ghrelin, on growth hormone release in rats. Biochemical and Biophysical Research Communications 275 477-480.

Date Y, Nakazato M, Murakami N, Kojima M, Kangawa K \& Matsukura S 2001 Ghrelin acts in the central nervous system to stimulate gastric acid secretion. Biochemical and Biophysical Research Communication 280 904-907.

Guan XM, Yu H, Palyha OC, McKee KK, Feighner SD, Sirinathsinghji DJ, Smith RG, Van der Ploeg LHT \& Howard AD 1997 Distribution of mRNA encoding the growth hormone secretagogue receptor in brain and peripheral tissues. Molecular Brain Research 48 23-29.

Hosoda H, Kojima M, Matsuo H \& Kangawa K 2000 Purification and characterization of rat des-Gln14-ghrelin, a second endogenous ligand for the growth hormone secretagogue receptor. Journal of Biological Chemistry 275 21995-22000.

Howard AD, Feighner SD, Cully DF, Arena JP, Liberator PA, Rosenblum CI, Hamelin M, Hreniuk DL, Palyha OC, Anderson J, Paress PS, Diaz C, Chou M, Liu KK, McKee KK, Pong SS, Chaung LY, Elbrecht A, Dashkevicz M, Heavens R, Rigby M, Sirinathsinghji DJ, Dean DC, Melillo DG \& Van der Ploeg LHT 1996 A receptor in pituitary and hypothalamus that functions in growth hormone release. Science 273 974-977.

Kojima M, Hosoda H, Date Y, Nakazato M, Matsuo H \& Kangawa K 1999 Ghrelin is a growth-hormone-releasing acylated peptide from stomach. Nature 402 656-660.

Lee H-M, Wang G, Englander EW, Kojima M \& Greeley GH 2002 Ghrelin, a new gastrointestinal endocrine peptide that stimulates insulin secretion: enteric distribution, ontogeny, influence of endocrine and dietary manipulations. Endocrinology 143 185-190.

McKee KK, Palyha OC, Feighner SD, Hreniuk DL, Tan CP, Phillips MS, Smith R G, Van der Ploeg LHT \& Howard AD 1997a Molecular analysis of rat pituitary and hypothalamic growth hormone secretagogue receptors. Molecular Endocrinology 11 415-423.

McKee KK, Tan CP, Palyha OC, Liu J, Feighner SD, Hreniuk DL, Smith RG, Howard AD \& Van der Ploeg LHT 1997 Cloning and characterization of two human $G$ protein-coupled receptor genes (GPR38 and GPR39) related to the growth hormone secretagogue and neurotensin receptors. Genomics 46 426-434. 
Nakazato M, Murakami N, Date Y, Kojima M, Matsuo H, Kangawa K \& Matsukura S 2001 A role for ghrelin in the central regulation of feeding. Nature 409 194-198.

Smith RG, Palyha OC, Feighner SD, Tan CP, McKee KK, Hreniuk DL, Yang L, Morriello G, Nargund R, Patchett AA \& Howard AD 1999 Growth hormone releasing substances: types and their receptors. Hormone Research 51 (Suppl 3) 1-8.
Tschop M, Smiley DL \& Heiman ML 2000 Ghrelin induces adiposity in rodents. Nature 407 908-913.

Received in final form 14 January 2002

Accepted 24 January 2002 